\title{
Fertility and Parental Labor Supply in Rural Northwestern China: Evidence From Twin Births
}

\author{
Qihui Chen ${ }^{1}$ (i) $^{\text {a }}$ \\ ${ }^{1}$ Beijing Food Safety Policy \& Strategy Research Base, College of Economics and Management, China Agricultural University, Beijing, China \\ Keywords: fertility, labor supply, rural china \\ https://doi.org/10.46557/001c.29959
}

\section{Asian Economics Letters}

Vol. 3, Issue 1, 2022

This study exploits twin births to identify the effects of fertility on parental labor supply in rural northwestern China. Instrumental variable estimation suggests that having an additional child reduces mothers' yearly labor supply by seven days and shifts their labor supply from wage work (a 10-day reduction) to farm work (a three-day increase). In contrast, paternal labor supply is unaffected by changes in fertility.

\section{Introduction}

This paper estimates the effects of fertility on parental labor supply in rural Northwestern China. The fertility-labor supply relation is of interest to researchers and policymakers, because it has important implications for population policy, childcare system development, and labor market regulations. Although the literature has documented a robust (negative) association between fertility and labor supply, the extent to which this association is causal remains unsettled. There could be unobservable factors (e.g., health endowments) that simultaneously affect parents' fertility and labor supply decisions. Twin births, as exploited by Angrist and Evans (1998) and Cáceres-Delpiano (2012), among others, provide a valuable opportunity to identify fertility effects. The present study also uses twinning as an instrumental variable (IV) to estimate the impact of fertility on parents' time allocation to different productive activities (i.e., farming, off-farm wage work, and selfemployment) in rural northwestern China.

Rural northwestern China is an important case to study. During China's transition to a market-oriented economy, its rural labor market has undergone profound structural transformations. Whereas off-farm employment had become a key source of household income by the early 2000s, there still existed barriers to off-farm labor supply (Bowlus \& Sicular, 2003; Li et al., 2017). Previous studies have identified many significant determinants of barriers to off-farm labor supply in rural China, such as (the low level of) education (Yang, 2004; Zhang et al., 2004), macroeconomic fluctuations (Zhang et al., 2001), industrial upgrades (Li et al., 2012), access to social protection (Su et al., 2017), and the development of rural land markets (Zhu et al., 2018). However, not until recently have researchers paid attention to the role of fertility (Guo et al., 2018; He \& Zhu, 2016; Tong
\& Gong, 2020). Rural northwestern China is the least developed region in China. The development of the childcare system and off-farm labor markets in rural northwestern China have lagged behind other areas, making this an interesting region for studying whether high fertility rates act as a barrier to off-farm labor supply.

We employ a data set on nearly 1,500 rural households randomly selected from Gansu, a typical province in northwestern China, to estimate the fertility-labor supply relation. Our IV estimation exploiting twinning finds that, while having an additional child shifts maternal labor supply from wage work to farm work, paternal labor supply is unaffected by changes in fertility.

This study makes two contributions to the literature. First, it examines an understudied population, rural parents in China, whereas most of the previous fertility-labor supply studies in China focus on its urban population ( $\mathrm{He} \&$ Zhu, 2016; Tong \& Gong, 2020). Although Guo et al. (2018) examine rural parents in China's Yunnan province, their study sample is not random (rather, half of their sample was chosen to match their sample of twins based upon residential locality). Second, our study analyzes not only parents' total labor supply, but also their time allocated to different productive activities, which enables us to observe the shift from off-farm to on-farm labor supply among mothers.

\section{Method}

Our estimation is based on the following model:

$$
L D_{i j}=\beta_{0 i j}+\beta_{1 i j} N \text { child }+X_{i j} \beta_{2 i j}+V+U_{i j}
$$

where $L D_{i j}$ is the number of yearly labor days parent $i$ ( $i$ representing either the father or mother) spent performing activity $j$ ( $j$ denoting either farming, self-employment, or off-farm wage work) $;^{1} N$ child is the number of children un-

\footnotetext{
a Corresponding author email: chen1006@umn.edu

1 One labor day is defined as eight hours worked. Off-farm wage work is defined as the work an individual performed (for at least 10 days in
} 
der age 18 in the family; $X$ is a set of family characteristics, including parental education, parental age, maternal age at first birth, and per capita landholdings and household assets; $V$ is a set of village fixed effects that helps control for factors varying at the village level (e.g., farm input prices and off-farm wages); and the error term $U$ captures the influence of unobserved factors.

If Equation (1) is correctly specified, the parameter $\beta_{1}$ measure the causal effects of fertility on parental labor supply and can be estimated by ordinary least squares (OLS). However, OLS estimates can be biased due to unobserved factors (e.g., health endowments) that simultaneously affect parents' fertility and labor supply decisions. Following Jacobsen et al. (1999), Cáceres-Delpiano (2012), and He and Zhu (2016), among others, we address the endogeneity of fertility by using an indicator of twin births, Twins, to instrument $N$ child, the number of children in the family. More specifically, we estimate Equation (1) jointly with the first-stage equation in a two-stage least squares framework:

$$
N \widehat{\text { child }}=\widehat{\alpha}_{0}+\widehat{\alpha}_{1} \times \text { Twins }+X \widehat{\alpha}_{2}+\widehat{V}
$$

\section{Data}

Our data are from the Gansu Survey of Children and Families (GSCF). Adopting a stratified random sampling strategy, the GSCF selected 2,000 rural families (20 counties $\times 5$ villages $\times 100$ children) with children aged 9-12 in the year 2000 from all non-urban, non-Tibetan counties in China's Gansu province. As a typical province in northwestern China, Gansu consists of a loess plateau, the Gobi Desert, mountainous/hilly areas, and vast grasslands. With three-quarters of its 25.4 million population residing in rural areas, Gansu is among the poorest in China. In 2004, our study period, Gansu's rural per capita net disposable income ranked 30th out of 31 provinces (National Bureau of Statistics, 2005).

The survey collected information on the target children, their parents, teachers, and local village leaders. Follow-up surveys were conducted in 2004, 2007, 2009, and 2015. Our study uses data from the second wave, collected in 2004, when the families had completed their fertility cycle and most of their children were of school age (with an average age of 14). The analysis focuses on 1,495 mothers under age 45 (and their husbands) whose children were all under 18 in 2004.

Table 1 depicts the profile of these parents. As is typical for residents in an underdeveloped area, both parents had a relatively low level of education and managed a limited amount of land. While fathers devoted a significant portion of their time to off-farm wage work, mothers spent more time on farm work. ${ }^{2}$ Consistent with previous findings, about $2.3 \%$ of the mothers experienced twin births (identified when two children in a family have the same birth year and month).

\section{Results}

Columns (1) and (2) in Table 2 present the estimated effects of fertility on mothers' total yearly labor supply. While both OLS and IV estimates suggest a negative impact of fertility on maternal labor supply, the impacts differ significantly in size, suggesting potential endogeneity in Nchild . A standard Hausman-Wu endogeneity test confirms that the difference between the OLS and IV estimates is (marginally) statistically significant $(F$-statistic $=2.71, p=$ 0.0998). The IV estimate (column (2)) indicates that rural mothers reduce their yearly labor supply by 7.4 labor days in response to an exogenous increase in fertility (due to twin births). In contrast, changes in fertility have no significant effect on their husbands' labor supply decisions (columns (4) and (5)).

The validity of the IV estimates hinges on that of the IV used. Thus, we perform a series of checks to assess the validity of our twin birth IV. First, supporting the relevance condition, first-stage regressions (Table 2, columns (3) and (6)) reveal little evidence of the weak IV problem (Bound et al., 1995). The F-statistics for testing the significance of the IV, 73.23 in column (3) and 70.44 in column (6), both greatly exceed the rule-of-thumb value of 10 (Staiger \& Stock, 1997). ${ }^{3}$ Second, to verify that twin births satisfy the exogeneity condition, we ran a set of regressions of the twin birth dummy on observed household characteristics. If twin births are subject to parental control, they are likely to be correlated with some of these characteristics. However, as Table 3 shows, none of these characteristics predicts twin births, whether separately in bivariate regressions (column (1)) or jointly in a multivariate regression (column (2)).

Table 4, panel A, further examines parents' time allocated to different productive activities in response to increases in fertility. The results suggest that mothers shift their labor supply from off-farm wage employment (column (4), a 10-labor-day reduction) to farm work (column (2), a nearly three-labor-day increase) in response to having an additional child. Mothers also tend to devote more time to self-employment, but the effect is not statistically significant. Again, fathers' labor supply responses to changes in fertility are generally quite limited. Interestingly, there seem to be substitutions between fathers' and mothers' time allocated to off-farm wage work and self-employment,

the previous year) as one of the following: factory worker, company staff, construction/mining worker, service industry worker, teacher, doctor, technician, soldier, township/village cadre member, and government clerk.

2 During the study period, very few parents ( $0.04 \%$ of all sampled mothers and $1.7 \%$ of all fathers) worked on a farm for a wage in Gansu. The top three off-farm wage jobs of the fathers in our sample were in construction/mining (28\%), services (24\%), and factory work (19\%), and their top three types of wage jobs were in services (36\%), construction/mining (10\%), and factory work (10\%).

3 Similar to the findings of He and Zhu (2016) and Guo et al. (2018), twinning increases the number of children by about 0.85 . The negative coefficients of per capita landholdings and household assets in the first-stage regressions (columns (3) and (6)) suggest that, conditional on twin births, children are considered "inferior goods" to rural parents; that is, rural parents demand fewer children as they become wealthier. 
Table 1. Variable definitions and summary statistics

\begin{tabular}{|c|c|c|c|c|c|}
\hline \multirow[t]{2}{*}{ (1) Variables } & \multirow[t]{2}{*}{ (2) Definitions } & \multicolumn{2}{|c|}{$\begin{array}{l}\text { (3) Mothers (under age 50; all } \\
\text { children under 18) }\end{array}$} & \multicolumn{2}{|c|}{$\begin{array}{l}\text { (4) Fathers (husbands of } \\
\text { mothers in (3)) }\end{array}$} \\
\hline & & Mean & SD & Mean & SD \\
\hline LDtotal & Total yearly labor days (days): & 32.78 & 54.10 & 105.47 & 109.39 \\
\hline LDfarm & Farm work (days) & 18.93 & 11.87 & 14.30 & 12.23 \\
\hline LDwage & Off-farm wage work (days) & 12.71 & 55.67 & 88.35 & 116.32 \\
\hline LDselfemp & Self-employment (days) & 1.15 & 5.22 & 2.82 & 7.75 \\
\hline $\begin{array}{l}\text { Moedu/ } \\
\text { Faedu }\end{array}$ & $\begin{array}{l}\text { Mother's/father's education } \\
\text { (years) }\end{array}$ & 4.22 & 3.02 & 6.58 & 2.94 \\
\hline $\begin{array}{l}\text { Age/Moage/ } \\
\text { Faage }\end{array}$ & Mother's/father's age (years) & 37.90 & 3.00 & 39.32 & 3.50 \\
\hline Moage $1 b$ & $\begin{array}{l}\text { Maternal age at first birth } \\
\text { (years) }\end{array}$ & 21.65 & 2.30 & & \\
\hline PCland & Per capita landholding $(m u)$ & 2.54 & 1.76 & & \\
\hline PCasset & $\begin{array}{l}\text { Per capita household assets } \\
\text { value (yuan) }\end{array}$ & 6434 & 11149 & & \\
\hline Twins & Indicator of twin births & 0.023 & 0.15 & & \\
\hline Nchild & Number of children under 18 & 2.23 & 0.65 & & \\
\hline
\end{tabular}

Notes: This table provides the short form names of variables and their definitions in columns (1) and (2), respectively. In columns (3) and (4), we report the mean and standard deviation (SD). $N=1,495$. One $m u=1 / 15$ hectare. One U.S. dollar=8.27 yuan in 2004 .

but the effects are not significant.

Finally, as further robust checks, we consider alternative specifications. First, we include child characteristics (including the average age, years of schooling, and the fraction of girls) in the model (Table 4, panel B); we expect these characteristics to be correlated with the number of children in the family. Second, to address potential reverse causality from labor supply to household and farm assets, we drop household assets and landholdings from the model (panel C). Finally, we expand the sample to include mothers under age 55 and their husbands (panel D) to account for potential life cycle effects. Reassuringly, none of these changes alter the findings of the fertility-labor supply relation discussed above. 
Table 2. Effects of fertility on parents' total yearly labor supply (days)

\begin{tabular}{|c|c|c|c|c|c|c|}
\hline & (1) & (2) & (3) & (4) & (5) & (6) \\
\hline & \multicolumn{3}{|c|}{ Mothers (under 50; all children under 18) } & \multicolumn{3}{|c|}{ Fathers (wife under 50; all children under 18) } \\
\hline & OLS & IV & $1^{\text {st }}$-stage & OLS & IV & $1^{\text {st-stage }}$ \\
\hline \multirow[t]{2}{*}{ IV: Twins } & & & $0.834^{* * *}$ & & & $0.866^{* * *}$ \\
\hline & & & $(0.097)$ & & & $(0.103)$ \\
\hline \multirow[t]{2}{*}{ Nchild } & -0.656 & $-7.354^{*}$ & & -7.462 & 3.477 & \\
\hline & $(2.294)$ & $(4.027)$ & & (4.541) & $(20.354)$ & \\
\hline \multirow[t]{2}{*}{ Moedu } & 0.486 & 0.406 & $-0.012^{*}$ & 1.907 & 2.023 & -0.010 \\
\hline & $(0.733)$ & $(0.704)$ & (0.006) & (1.251) & (1.248) & $(0.006)$ \\
\hline \multirow[t]{2}{*}{ Faedu } & 0.512 & 0.525 & 0.002 & $3.095^{* * *}$ & $3.035^{* * *}$ & 0.005 \\
\hline & $(0.505)$ & $(0.487)$ & $(0.006)$ & $(1.056)$ & $(1.027)$ & $(0.006)$ \\
\hline \multirow[t]{2}{*}{ Age } & $-23.260^{*}$ & $-23.657^{*}$ & -0.034 & 12.789 & 11.004 & $0.170^{* *}$ \\
\hline & (13.303) & (12.760) & (0.119) & (9.666) & $(10.220)$ & $(0.077)$ \\
\hline \multirow[t]{2}{*}{$A g e^{2}$} & $0.300^{*}$ & $0.314^{*}$ & 0.002 & -0.161 & -0.142 & $-0.002^{*}$ \\
\hline & $(0.179)$ & (0.173) & $(0.002)$ & $(0.115)$ & $(0.120)$ & $(0.001)$ \\
\hline \multirow[t]{2}{*}{ Moage $1 b$} & -1.082 & -1.827 & $-0.111^{* * *}$ & $-3.555^{* *}$ & $-3.150^{* *}$ & $-0.038^{* * *}$ \\
\hline & (1.072) & (1.235) & $(0.011)$ & $(1.502)$ & (1.563) & (0.008) \\
\hline \multirow[t]{2}{*}{ PCland } & -0.253 & -1.841 & $-0.222^{* * *}$ & 1.892 & 4.437 & $-0.217^{* * *}$ \\
\hline & (3.534) & (3.579) & $(0.054)$ & (6.651) & (8.018) & $(0.056)$ \\
\hline \multirow[t]{2}{*}{ Log(PCasset) } & -0.138 & -0.550 & $-0.059^{* *}$ & 1.439 & 2.105 & $-0.057^{* *}$ \\
\hline & $(1.756)$ & (1.728) & $(0.024)$ & (3.701) & (3.780) & $(0.024)$ \\
\hline Village FE & yes & yes & yes & yes & yes & yes \\
\hline$N$ & 1,495 & 1,495 & 1,495 & 1,495 & 1,495 & 1,495 \\
\hline $\mathrm{R}^{2}$ & 0.145 & 0.140 & 0.326 & 0.206 & 0.202 & 0.284 \\
\hline
\end{tabular}

Notes: Columns (1) and (4) report OLS regression results; columns (2) and (5) report IV estimation results; and columns (3) and (6) report first-stage regression results. Robust standard errors are reported in parentheses, adjusted for intra-village clustering, and ${ }^{* * * *} \mathrm{p}<0.01, * * \mathrm{*}<0.05, * \mathrm{p}<0.1$. 
Table 3. Correlations between twin births and household characteristics

\begin{tabular}{|c|c|c|}
\hline & (1) & (2) \\
\hline Outcome variables: Twin-birth indicator & Bivariate regressions & Multivariate regression \\
\hline \multirow[t]{2}{*}{ Moedu } & 0.000 & -0.001 \\
\hline & $(0.001)$ & $(0.002)$ \\
\hline \multirow[t]{2}{*}{ Faedu } & 0.001 & 0.001 \\
\hline & $(0.001)$ & $(0.001)$ \\
\hline \multirow[t]{2}{*}{ Moage } & -0.000 & -0.001 \\
\hline & $(0.001)$ & $(0.001)$ \\
\hline \multirow[t]{2}{*}{ Moage $1 b$} & -0.000 & 0.002 \\
\hline & $(0.001)$ & $(0.003)$ \\
\hline \multirow[t]{2}{*}{ Faage } & -0.001 & 0.000 \\
\hline & $(0.001)$ & $(0.003)$ \\
\hline \multirow[t]{2}{*}{ PCland } & -0.001 & -0.001 \\
\hline & $(0.005)$ & $(0.005)$ \\
\hline \multirow[t]{2}{*}{$\log (P$ Casset $)$} & -0.004 & -0.001 \\
\hline & $(0.138)$ & $(0.003)$ \\
\hline$N$ & 1,495 & 1,495 \\
\hline $\mathrm{R}^{2}$ & & 0.002 \\
\hline
\end{tabular}

Notes: Each row in column (1) reports the coefficient estimated from a bivariate regression of the twin-birth indicator on the explanatory variable in that row; column (2) reports coefficients from a multivariate regression of the twin-birth indicator on all explanatory variables on the left. Robust standard errors are reported in parentheses, adjusted for intra-village clustering. 
Table 4. 2SLS estimates of fertility effects on parental labor supply

\begin{tabular}{|c|c|c|c|c|c|c|c|c|}
\hline \multirow[b]{3}{*}{$\begin{array}{l}\text { Yearly labor days } \\
\text { spent on: }\end{array}$} & (1) & (2) & (3) & (4) & (5) & (6) & (7) & (8) \\
\hline & \multicolumn{4}{|c|}{ Mothers (under 50; all children under 18) } & \multicolumn{4}{|c|}{ Fathers (wife under 50; all children under 18) } \\
\hline & $\begin{array}{l}\text { Farm work } \\
\text { (LDfarm) }\end{array}$ & $\begin{array}{l}\text { Off-farm wage work } \\
\text { (LDwage) }\end{array}$ & $\begin{array}{l}\text { Self-employed } \\
\text { (LDselfemp) }\end{array}$ & $\begin{array}{l}\text { Total } \\
\text { (LDtotal) }\end{array}$ & $\begin{array}{l}\text { Farm work } \\
\text { (LDfarm) }\end{array}$ & $\begin{array}{l}\text { Off-farm wage work } \\
\text { (LDwage) }\end{array}$ & $\begin{array}{l}\text { Self-employed } \\
\text { (LDselfemp) }\end{array}$ & $\begin{array}{c}\text { Total } \\
\text { (LDtotal) }\end{array}$ \\
\hline & \multicolumn{8}{|c|}{ A. Same specifications as in Table 2} \\
\hline Nchild & $2.929^{* *}$ & $-10.270^{* *}$ & 0.646 & $-7.354^{*}$ & 1.177 & 2.942 & -0.642 & 3.477 \\
\hline \multirow[t]{2}{*}{$N=1,525$} & $(1.188)$ & $(4.349)$ & $(0.947)$ & $(4.027)$ & $(1.664)$ & $(21.394)$ & $(1.025)$ & $(20.354)$ \\
\hline & \multicolumn{8}{|c|}{ B. Average child characteristics added } \\
\hline Nchild & $3.132^{* *}$ & $-12.475^{* *}$ & 0.836 & $-8.507^{*}$ & 1.450 & 0.841 & -0.552 & 1.739 \\
\hline \multirow[t]{2}{*}{$N=1,525$} & $(1.412)$ & $(5.547)$ & $(1.093)$ & $(4.723)$ & $(1.825)$ & $(23.213)$ & $(1.089)$ & $(22.047)$ \\
\hline & \multicolumn{8}{|c|}{ C. Household assets and landholding dropped } \\
\hline Nchild & $2.475^{* *}$ & $-9.712^{* *}$ & 0.599 & $-6.639^{*}$ & 1.201 & 1.181 & -0.751 & 1.631 \\
\hline \multirow[t]{2}{*}{$N=1,525$} & $(1.112)$ & $(4.184)$ & $(0.959)$ & (3.571) & $(1.604)$ & $(20.434)$ & $(0.936)$ & (19.450) \\
\hline & \multicolumn{8}{|c|}{ D. Sample: "mother's age $\leq 55$ " } \\
\hline Nchild & $2.926^{* *}$ & $-10.245^{* *}$ & 0.660 & $-6.660^{*}$ & 1.279 & 0.162 & -0.588 & 0.854 \\
\hline$N=1,536$ & (1.172) & (4.395) & $(0.948)$ & (3.733) & (1.658) & (21.333) & (1.031) & (20.290) \\
\hline
\end{tabular}

Notes: Unless otherwise indicated, all models include the full set of control variables as noted in Table 2. Robust standard errors are reported in parentheses, adjusted for intra-village clustering, and ** and * denote $p<0.05$ and p $<0.1$, respectively. 


\section{Conclusion}

Using twin births to instrument fertility, this study finds that having an additional child reduces mothers' yearly labor supply by seven days and shifts their labor supply from off-farm wage work (a 10-day reduction) to farming (a three-day increase) in rural northwestern China. Paternal labor supply is much less affected by changes in fertility.

Several policy suggestions can be drawn from these findings. First, despite the recent relaxation of China's population control policy, family planning strategies could still be needed to improve labor market outcomes for households residing in China's least developed areas. Second, a well-functioning childcare system should be developed in rural (northwestern) China to help release more female labor from the farming sector. Job training programs could also help assist rural mothers in finding off-farm work.

Submitted: July 15, 2021 AEDT, Accepted: August 24, 2021 AEDT 


\section{REFERENCES}

Angrist, J. D., \& Evans, W. N. (1998). Children and their parents' labor supply: Evidence from exogenous variation in family size. American Economic Review, $88,450-477$.

Bound, J., Jaeger, D. A., \& Baker, R. M. (1995). Problems with instrumental variables estimation when the correlation between the instruments and the endogenous explanatory variable is weak. Journal of the American Statistical Association, 90(430), 443-450. https://doi.org/10.1080/01621459.1995.10476536

Bowlus, A. J., \& Sicular, T. (2003). Moving toward markets? Labor allocation in rural China. Journal of Development Economics, 71(2), 561-583. https://doi.or $\mathrm{g} / 10.1016 / \mathrm{s} 0304-3878(03) 00040-3$

Cáceres-Delpiano, J. (2012). Can we still learn something from the relationship between fertility and mother's employment? Evidence from developing countries. Demography, 49(1), 151-174. https://doi.or g/10.1007/s13524-011-0076-6

Guo, R., Li, H., Yi, J., \& Zhang, J. (2018). Fertility, household structure, and parental labor supply: Evidence from China. Journal of Comparative Economics, 46(1), 145-156. https://doi.org/10.1016/i.j ce.2017.10.005

He, X., \& Zhu, R. (2016). Fertility and female labour force participation: Causal evidence from urban China. The Manchester School, 84(5), 664-674. http s://doi.org/10.1111/manc.12128

Jacobsen, J. P., Pearce, J. W., III, \& Rosenbloom, J. L. (1999). The effects of childbearing on married women's labor supply and earnings: using twin births as a natural experiment. Journal of Human Resources, 34(3), 449-474. https://doi.org/10.2307/146376

Li, H., Li, L., Wu, B., \& Xiong, Y. (2012). The end of cheap Chinese labor. Journal of Economic Perspectives, 26(4), 57-74. https://doi.org/10.1257/jep.26.4.57
Li, H., Loyalka, P., Rozelle, S., \& Wu, B. (2017). Human capital and China's future growth. Journal of Economic Perspectives, 31(1), 25-48. https://doi.org/10.1257/je p.31.1.25

National Bureau of Statistics. (2005). China Statistical Yearbook 2005 (in Chinese). China Statistical Publishing House.

Staiger, D., \& Stock, J. H. (1997). Instrumental variables regression with weak instruments. Econometrica, 65(3), 557-586. https://doi.org/10.2307/2171753

Su, B., Thierry, G. H., Chen, Q., \& Zhao, Q. (2017). The New Cooperative Medical Scheme and selfemployment in rural China. Sustainability, 9(2), 304. h ttps://doi.org/10.3390/su9020304

Tong, Y., \& Gong, Q. (2020). The impact of child births on female labor force participation in China. China Population and Development Studies, 3(3), 237-251. ht tps://doi.org/10.1007/s42379-019-00041-6

Yang, D. T. (2004). Education and allocative efficiency: Household income growth during rural reforms in China. Journal of Development Economics, 74(1), 137-162. https://doi.org/10.1016/j.jdeveco.2003.12.00 7

Zhang, L., de Brauw, A., \& Rozelle, S. (2004). China's rural labor market development and its gender implications. China Economic Review, 15(2), 230-247. https://doi.org/10.1016/j.chieco.2004.03.003

Zhang, L., Rozelle, S., \& Huang, J. (2001). Off-farm jobs and on-farm work in periods of boom and bust in rural China. Journal of Comparative Economics, 29(3), 505-526. https://doi.org/10.1006/jcec.2001.1728

Zhu, W., Luo, B., \& Paudel, K. (2018). The Influence of Land Titling Policy on the Rural Labor Migration to City: Evidence from China [Paper]. 2018 AAEA Annual Meeting. 